\title{
A novel integrated assessment methodology of urban water reuse
}

\author{
A. Listowski, H. H. Ngo* , W.S. Guo and S. Vigneswaran \\ Faculty of Engineering and Information Technology, University of Technology, \\ Sydney, \\ P.O. Box 123, Broadway, NSW 2007, Australia \\ * Correspondence author, Tel: +61-2-9514-1693, Fax: + 61-2-9514-2633, \\ E-mail: h.ngo@uts.edu.au
}

\begin{abstract}
Wastewater is no longer considered a waste product and water reuse needs to play a stronger part in securing urban water supply. Although treatment technologies for water reclamation have significantly improved the question that deserves further analysis is, how selection of a particular wastewater treatment technology relates to performance and sustainability? The proposed assessment model integrates; (i) technology, characterised by selected quantity and quality performance parameters; (ii) productivity, efficiency and reliability criteria; (iii) quantitative performance indicators; (iv) development of evaluation model. The challenges related to hierarchy and selections of performance indicators have been resolved through the case study analysis. The goal of this study is to validate a new assessment methodology in relation to performance of the microfiltration (MF) technology, a key element of the treatment process. Specific performance data and measurements were obtained at
\end{abstract}


specific Control and Data Acquisition Points (CP) to satisfy the input-output inventory in relation to water resources, products, material flows, energy requirements, chemicals use, etc. Performance assessment process contains analysis and necessary linking across important parametric functions leading to reliable outcomes and results. Keywords: assessment methodology; performance evaluation; water reuse.

\section{INTRODUCTION}

Sustainable water management requires thorough consideration of various disciplines influencing relationships between treatment process and technology, resources management, scheme management and operation, environment, community and the economy. Research and technology play crucial role in performance of the treatment processes and achieving recycled water quality, while scheme management influence economic performance, compliance with the environmental standards and gaining public satisfaction; all complements the sustainable out- come. Future cities will depend on integrated water cycle strategies, consolidation of all available water resources, effective management and research of advanced treatment technologies that could secure new water supply. There is a growing need to develop urban water cycle assessment methods that could integrate technology and sustainability aspects beyond current supply and demand management.

Technologies used for water reclamation are well developed, however the quest for thorough understanding of all critical operational aspects and function associated 
with technology performance still causes concerns during the development of water reuse scheme. When it comes to technology selection, a common dilemma relates to uniform performance assessment. Technology selection criteria are still dominated by capital costs and estimates of future maintenance and operating costs, accompanied by specifications and performance assurances by process designers and technology manufacturers. Treatment technologies are regularly customised to meet variable input/output and water quality and quantity criteria. Equally the same divergence applies to selection of assessment criteria and performance indicators with preferences scattered across an entire spectrum of treatment technologies, quality standards, risk management, costs, environmental or social impact.

The linkages between theory and practice and possibility of potential repeatability and comparability of assessment methodology are unconventional to case studies at present. Undeniably scientific case studies provide valuable context and knowledge that in combination with appropriately constructed framework would produce uniform outcome. The challenge of technology performance starts usually with the definition of the process, identification and characterisation of fundamental technological parameters. While this process seems quite straightforward, it is often hindered by the deficiency of operating data.

Although practice oriented research method endeavour towards holistic characterisation of the system, in the context of complex technologies, it could be also applied to examine a specific aspect of the treatment process. 


\section{PRACTICE ORIENTED RESEARCH VERIFICATION METHODOLOGY}

This report is prepared as part of the more comprehensive study on assessment of urban water reuse scheme and is dealing with microfiltration (MF) of secondary effluent from a sequencing batch reactor processing domestic wastewater. MF has been deservedly recognised as a process for effluent clarification and a physical means of disinfection or microbial removal. Perhaps the most important factor is that it is constantly producing high-quality water. The objectives of this case study include the following:

- Selection of specific MF performance indicators;

- Evaluation of MF performance under actual operating conditions;

- MF productivity, efficiency and reliability;

- Comparative analysis and repeatability of methodology.

The uniqueness and strength of practice oriented research method lays in the following factors:

- Strong relationship between scientific theory and practice;

- Systematic assessment protocol;

- Data acquisition;

- Evaluation process based on predetermined criteria.

Membrane performance is usually modeled using empirical laws, coefficients, equations, etc. However, despite certain contribution to science, it often does not offer accurate or practical solutions. The challenge for membrane performance assessment rests with adopting more realistic and less complicated 
method without oversimplifying and neglecting actual conditions. This study is focusing on exploring interactions between treatment process dynamics, membrane properties, characteristics of liquids and substances as shown in (Figure 1). In a broader sense this assessment follows principles of a mass transfer, in which flow through particular treatment phase(s) occurs either as batch or continuously. Traditionally assessment process of water reclamation scheme is focusing on specifications, hydrodynamics, costs and compliance with guidelines and regulatory requirements. Progressively understanding of integrated performance assessment is gradually improving, but evaluation techniques appear underdeveloped, lacking consistent methodology, while decisions are still dominated by market transactions. Most assessment methodologies involve mainly qualitative environmental impact, risk profile analysis and more popular public acceptance studies.

This model incorporates the following steps and principles:

- Technology characterisation;

- Determination of measurable technology performance indicators;

- Performance assessment involving, productivity, efficiency and reliability criteria.

While technology is important to overall scheme, the question that deserves further analysis is how selection of a particular treatment technology affects overall economic, environmental, and social sustainability? So far, there are no agreements on the representative analytical framework, methodology or performance assessment that regard technology as a focal point of the process. 
Commencing with quantitative and qualitative instruments creates new lines of thinking by the emergence of fresh perspectives as both measures are imperative for any subsequent evaluations. The immediate challenge at this point is the decision of which performance indicators are essential, provide sufficient performance representation and should be included in the model, without limiting this research? The answer of hierarchy ands election was obtained through analysis of data procured from WRAMS operation (MHW 2007).

\section{WRAMS - TREATMENT PROCESS DESCRIPTION}

The Water Reclamation and Management Scheme (WRAMS) was built as part of the Sydney Olympics in 2000. The Scheme comprises of an activated sludge sequencing batch reactors, microfiltration, and reverse osmosis, UV and final disinfection processes. It has been designed to treat domestic sewage and stormwater and to produce high quality recycled water which is supplied to residential and commercial customers. The main elements of WRAMS are; Water Reclamation Plant (WRP), Water Treatment Plant (WTP), stormwater collection and storage management and recycled water distribution systems.

\subsection{Water Reclamation Plant (WRP)}

The WRP is the first step in water reuse. It employs sequencing batch reactor (SBR) technology, capable of removing solids, phosphorus, BOD and ammonia. Its average and peak treatment capacities are $2,200 \mathrm{~m}^{3}$ per day and $3,100 \mathrm{~m}^{3}$ per day, 
respectively. The SBR system is performing at $4 \mathrm{~h} /$ cycle under the following sequence:

- Filling; this process takes approximately $60 \mathrm{~min}$ and in order to maintain suitable food to microorganism, wastewater is admitted in a rapid and controlled manner.

- Reaction, aerobic and mixed anoxic reactions. This stage involves the utilization of biochemical oxygen demand (BOD) and ammonia nitrogen, where applicable, by micro- organisms. This process takes approximately $120 \mathrm{~min}$.

- Settling, at this stage any aeration is stopped and the sludge settles leaving clear, treated effluent above the sludge blanket. This process takes approximately $60 \mathrm{~min}$.

- Decanting, the supernatant water is removed from the tank through the decanter, without disturbing the settled sludge. This process takes approximately $60 \mathrm{~min}$.

Aluminium Sulphate (Alum) is added at the end of each aeration cycle to achieve required removal of phosphorus. The WRP also has preliminary treatment consisting of screening and grit removal installation. Waste sludge is pumped to a sludge dewatering belt press and after achieving 4\% solids concentration is disposed off site. The secondary effluent from the WRP undergoes ultraviolet (UV) disinfection prior being transferred for further treatment to the WTP.

\subsection{Water Treatment Plant (WTP)}


The WTP has been designed to treat secondary effluent and stormwater (Figure 2). It consists of $7500 \mathrm{~m} 3 / \mathrm{d}$ continuous microfiltration (MF) and $2000 \mathrm{~m}^{3} / \mathrm{d}$ reverse osmosis (RO) membranes. The MF filters are $0.2 \mu \mathrm{m}$, hollow fibre filters arranged in three blocks consisting of 90 filter modules. In consideration of microfiltration treatment capacity the following criteria have been considered:

- Average day recycled water demand;

- Yield from sewage and stormwater resources;

- Required purity of product water;

- Technical characteristics and efficiency of microfiltration equipment; and

- Ease of scale up, expansion and retrofication.

The role of two RO modules, with a designed flow rate of $1000 \mathrm{~m}^{3} /$ day each, is to reduce conductivity of stormwater and produce high quality recycled water. The permeate from the MF and RO filters flows to a chlorine contact tank and then to a $8000 \mathrm{~m}^{3}$ underground recycled water reservoir, from there is pumped to recycled water distribution network. A Supervisory Control and Data Acquisition (SCADA) system is responsible for monitoring and distributed control of the WRAMS operation.

\section{WATER SOURCES CHARACTERISATION}

\subsection{Sewage Influent Quality}

The wastewater entering treatment process is collected from the residential and non-residential community. The sewage components, that most wastewater treatment 
plants are designed to remove include: suspended solids, biodegradable organics, and pathogenic organisms. In addition there are other characteristics e.g. colour, odour, temperature, $\mathrm{pH}$ and turbidity that provide information about the amount and type of pollutants present. Table 1 identifies the wastewater characteristics that affect the design, process effectiveness, energy use and cost.

Although the range of typical constituents in urban wastewater can vary considerably, decentralized schemes are more likely to have more predictable, stable patterns of wastewater quality. Characterisation of wastewater quality is important for identification and quantification of target constituents that need to be treated and removed.

\subsection{Stormwater Quality}

Stormwater is well incorporated into the whole water cycle and it is a second source of raw water used in the Water Treatment Plant. Typical constituents of concern in stormwater runoff from urban drainage include tar, oil, grease and metals (Table 2). Due to saline water intrusion into the storage, recorded total dissolved solids (TDS) range from 1,600 to 2,000 mg/L. That necessitates application of RO membranes. With a growing demand for recycled water, stormwater is regularly supplemented to meet peak demand, especially during the hot summer months where demand for onsite irrigation water is high. The treatment components of stormwater involve MF, RO and final disinfection 


\subsection{Recycled Water Quality}

Water quality management deals with a range of issues related to original source, treatment process, physical, chemical and microbiological quality of recycled water and its defined applications (Crichlow 2005). Table 3 illustrates results of recycled water sampling and its comparison with potable water quality.

The treatment process configuration and technology incorporated into WRAMS has a specific aim of producing high quality recycled water, for a wide range of non-potable water uses, while ensuring environmental protection, public health and safety. Currently approved recycled water uses include:

- Unrestricted irrigation of parklands, gardens and playing fields,

- Clothes washing,

- Ornamental water features and fountains,

- Toilet flushing,

- External wash down,

- Fire fighting,

- Construction,

- Cooling towers,

- Backwashing swimming pool filters.

\subsection{Mass Balance - Integrated Urban Water Resources}

WRAMS makes important contributions to the theory and practice of integrated resources management in the broader context. Integration means that urban water 
management considerations are given to the interaction and collective impact of all water related urban processes on issues such as human health, environmental protection, quality of receiving waters, water demand, land and water-based recreation, and stakeholder satisfaction (IWA 2002). The fundamental planning, concept design, functions and operating principles of WRAMS are arranged as an integrated water cycle that recognises values and dependency between different urban water resources. Annual water mass balance and demand data has been adapted to reflect interdisciplinary nature of analysis and setting up integrated model (see Table 4). Mass balance modelling is contingent on spatial and temporal consistency of information, while uniformity will enable comparison of results. This method enables real reconstruction of hydrodynamic process, analysis and interpretability of data, while corresponding to actual source of water masses.

\section{MICROFILTRATION - QUANTITATIVE ASSESSMENT}

Concise focus on technological process, quantitative and qualitative information is providing a gateway platform for technology performance characterization that leads to reliable outcomes and results. Subsequent performance assessment process contains analysis, synthesis by necessary linking across important parametric functions and is done against a set of standards and comparable benchmarks (see Table 5).

Quantitative performance verification and assessment tools are vital for management of water reuse technology. While evaluation techniques are slowly 
developing, they depend on systematic data collection, objective measurements, analysis and evidence interpretation in relation to process inputs and outputs. Resolution could be relatively easy when dealing with a simple process, but it becomes difficult when it involves a complex integrated water cycle scheme. To solve this issue, a specific process control system has been established at nominated points of the treatment process. Control \& Data Acquisition Points (CP) are capable of tracking performance at specific locations and production phases with respect to physical and bio-chemical functions. They provide input data for performance measures, the input-output inventory in relation to water resources, products, material flows, energy requirements, chemicals, etc. Depending on the required degree of analysis these indicators could be further enhanced and combined with a range of other specific parameters such as membrane flux, fouling potential, transmembrane pressure (TMP), etc. or used to verify manufacturer's technical standards.

\section{MICROFILTRATION (MF) - QUALITATIVE ASSESSMENT}

Qualitative assessment is based upon application of scientific analysis, knowledge, experience and judgment to determine whether technology, processes and management procedures that are in place are achieving required water quality standards. The general configuration of water reclamation process include: biological treatment, followed by membrane treatment involving microfiltration and reverse osmosis (Ghayeni et al. 1996; Johnson et al. 1997). Microfiltration is often seen as pretreatment and enhancements of the RO permeate flux (Adham et al. 1997). Both 
microfiltration and biological processes can be coupled in many ways or operated independently. MF is applied with a transmembrane pressure between 10 to $300 \mathrm{kPa}$ on particles and molecules of various sizes and shapes. The interactions between particles and membranes are important factors in considering classification of separation process and rejection ratios. Pore sizes of membranes represent only predicted average value, thus any definitive theoretical classification and specification of microfiltration process according to retention rate is not accurate. Therefore, some moderate overlaps in membranes classification are expected supporting higher than designed rejection rates. Measurement of the key chemical and biological parameters (see Tables 6and 7) provide indication of the degradation rate occurring in these materials. The removal rate of components was calculated by comparing concentration in the filtrate with the concentration of pollutants in the feed water in accordance with the following

Equation (1):

$\mathrm{R}=\left(1-\frac{C_{f t}}{C_{f d}}\right) 100 \%$

where $\mathrm{R}$ is the removal rate $(\%), \mathrm{C}_{\mathrm{ft}}$ the concentration in the filtrate and $\mathrm{C}_{\mathrm{fd}}$ the concentration in the feed.

The quality of feed water from secondary effluent or stormwater has a direct effect on the performance of microfiltration system. Microfiltration with membranes of $0.2 \mu \mathrm{m}$ pore size provided reliable filtrate quality and removal rate of major pollutants on a continuous basis. 


\section{MICROFILTRATION - PRODUCTIVITY ASSESSMENT}

The productivity of microfiltration membranes is measured by the following alternative methods:

- Volume offlow that can pass through a unit area of membrane surface and is commonly referred to as the 'flux rate'.

- Removal of particulate contaminants from a feed stream by separation based on retention of contaminants on a membrane surface.

MF productivity assessment could be calculated by evaluating decline influx over time. Flux rates are typically measured in units of litres of flow per square meter of membrane per hour $\left(\mathrm{L} / \mathrm{m}^{2} / \mathrm{h}\right)$. Typical values for microfiltration membranes range from 25 to 50 or more, depending upon the amount of solids and chemicals in the feed streams. The productivity index (see Table 8) of MF represents the volume of product water obtained from the total mass of influent and it could be calculated using the following Equation (2)

$P_{1}=\frac{\text { output }}{\text { Input }}$

where $\mathrm{P}_{1}$ is the productivity index.

\section{MICROFILTRATION - RELIABILITY ASSESSMENT}

Reliability assessment involves both theoretical and empirical considerations that are characterised with the tendency towards consistency of measured results. The reliability assessment relies on selection of typical parameters, ranges and variability 
of measurements and operational records (observation) that characterise microfiltration technology. These fall into the following categories:

- Properties and performance of membrane materials;

- Monitoring, detection and elimination of defects in the membrane;

- Process and plant operation; and

- Data analysis and statistics of treatment plant performance.

The predominant factors of microfiltration reliability relates to membrane fouling. Due to the influence of membrane fouling, prediction of the filtration performance for biological suspensions is difficult (Gallagher et al. 2001).

An average concentration values should be used to demonstrate consistency and a certain reliability level. Table 9 shows data for a group of constituents that were tested daily over the period of four weeks. The results show some degree of variability which is natural with the type of treatment process.

Operational reliability of MF membrane is related to its availability over time and it accounts for downtime due to membranes failures that are not predicted by the plant operator, but excludes operational backwashing, CIP and maintenance. Essentially reliability could be interpreted as unplanned capacity losses due to downtime, slowdown, shutdown, etc (Beirchfield 2000). Study of reliability could be performed on the whole treatment process or on its individual components and involves computation of the following parameters:

- Total time available for continues process TTA (h);

- Time of operation between failures (TBF) (h); 
- Downtime required for carrying out repairs (TOR) (h);

- Reliability index (ROPS)

$R_{O P S}=\left(\frac{T T A-T B F}{T B F+T O R}\right) 100 \%$

Reliability Index Equation (3) could be applied to compare manufacturer's specified time of operation with actual data obtained from the operating facility. WRAMS microfiltration system has been operating for over 9 years during which only a minor downtime was encountered. The two year records have been used to calculate operational reliability index and is summarised in Table 10.

\section{MICROFILTRATION - EFFICIENCY ASSESSMENT}

There is a limited research activity in the areas of measuring efficiency and productivity of wastewater reuse mainly due to unavailability of operational data and the lack of suitable performance indicators. The most apparent measurement method is the relation between output to input value. In the input orientation the efficiency scores relate to the largest feasible proportional reduction in inputs for fixed outputs, while in the output orientation it corresponds to the largest feasible proportional expansion in outputs for fixed inputs (Coell iet al. 2003). The efficiency of membrane filtration process is defined by:

- Measurement of filtrate flux; and

- Analysis of the bio-chemical content of pollutants in filtrate.

The quality of secondary effluent leaving the SBR process is generally good, but it is vulnerable tofluctuations arising from inconsistency of wastewater source, 
microbial activities, bulking and foaming occurring in the aeration tank affecting solids settling and separation (Bai \& Leow 2002). To assess membrane production efficiency the following microfiltration efficiency index Equation (4) $\mathrm{M}_{\mathrm{EF}}$ was applied:

$M_{E F}=\frac{T F_{F T}}{T F_{O}} \times 100 \%$

where $\mathrm{TF}_{0}$ is the total feed volume and $\mathrm{TF}_{\mathrm{FT}}$ the total filtrate production volume.

An example of MF analysis based on water recovery rate at WRAMS are summarised in Table 11.

MF is providing effective barrier for solids transmission and separation. As a consequence, it is subjected to progressive cake formation, pore blocking, causing flow resistance, increased reduction of filtrate flux and membrane fouling.

Membrane pollutants removal efficiency (PEF) reflects on the overall removal from sequential treatment and refers to the percent destruction, degradation, conversion, or removal of the pollutants. Percent removal Equation (5) can be calculated as follows:

$P_{E F}=\frac{I_{I N F}-E_{E F L}}{I_{I N F}} \times 100(\%)$

where $\mathrm{I}_{\mathrm{INF}}$ is the amount in the influent wastewater stream and $\mathrm{E}_{\mathrm{EFL}}$ the amount in the effluent waste stream (measured at applicable Control Point in sequence).

The result of membranes efficiency on physical and chemical parameters is shown in Table 12.

\section{EFFICIENCY OF ENERGY AND CHEMICALS USE}


Energy calculations of kilowatt hour/kilolitre ratios for each treatment plant have allowed plants to be ranked on the basis of their energy efficiency. Energy and chemicals used in membrane process are calculated in relation to filtrate production are shown in Table 13 and include:

- Effluent pumping;

- Backwash gas generation by compressor;

- CIP pumping;

- Retentate disposal;

- Filtrate disposal.

Despite periodic backwashing, MF membranes will slowly foul. In order to maintain system performance over extended period of time, chemical cleaning is employed to clean and sterilize the membrane. Chemical cleaning techniques include; acid cleaning, caustic cleaning, or use of proprietary solutions. MF membranes cleaning in place (CIP) is usually performed every four weeks. Citric acid is regarded as a suitable cleaning agent. Temperature control is improving efficiency of CIP process.

\section{CONCLUSIONS}

This benchmark study incorporates practical technology performance measures and relationship between input, processes and output parameters. It was undertaken to evaluate performance of microfiltration (MF) technology for the purpose of wastewater and stormwater treatment and for production of recycled water. This study 
forms part of the research of the assessment framework and methodology for sustainable water reclamation and reuse and integrates technology, environmental, social and economic performance criteria. The main strength of this pilot case study is in revealing that it is necessary to follow a specific procedure in conducting performance analysis and to follow five fundamental performance assessment criteria:

- Quantity, quality assessment;

- Productivity;

- Reliability; and

- Efficiency.

It is prudent to confirm that the assessment criteria can be applied to entire process, individual components of the scheme as well as specific technologies forming part of the treatment train. The uniqueness and strength of practice oriented research method lays in the following factors:

- Strong relationship between scientific theory and practical objectives;

- Systematic assessment protocol;

- Specific data acquisition and analysis;

- Evaluation process based on predetermined set of assessment criteria and performance indicators;

- Comparative outcome between large number of instances.

Although practice oriented research method endeavor towards holistic characterisation of the system, in the context of complex technologies, it could be also applied to examine a specific aspect of the treatment process. There is no single 
determination for membrane optimal operating conditions and most favorable use/life scenario. Use of these evaluation programs could result in better decision making process and reduction of the cost for new and existing products and services; to redesign internal processes, increasing productivity and quality.

\section{ACKNOWEDGEMENT}

This research was funded by Australian Research Council (ARC) Industry Linkage Grant (LP0882089).

\section{REFERENCES}

Adham, S., Trussell, R., Gagliardo, P., Weibberg, K. \& Richardson, T. 1997. Development of an innovative advanced treatment system for indirect potable reuse. In Proceedings of the World Congress on Desalination and Water Reuse, 6-9 October, Vol. II, Madrid, pp. 503-507.

Bai, R. B. \& Leow, H. F. 2002. Microfiltration of activated sludge wastewater. The effect of system operation parameters. Separation Purification Technology29, 189.

Beirchfield, G. 2000. Olefin Plant Reliability, Presented at Aspen World 2000. Available from: http://www.aspentech.com/publication_files/olefinsreliability.pdf (accessed date January 22, 2010).

Coelli, T. J., Estache, A., Perelman, S. \& Trujillo, L. 2003. A Primer on Efficiency Measurement for Utilities and Transport Regulators. World Bank Institute, Washington, DC. 
Crichlow, M. 2005. Water Quality Management, Eco EngNewsletter No. 11, October 2005.

Gallagher, P. M., Aaron, T., Balczewski, J. \& Cargnel, D. A. 2001. Method of Cleaning Membranes, Cambridge, MA, US.

Ghayeni, S. B., Madaeni, S. S., Fane, A. G. \& Schneider, R. P. 1996. Aspects of microfiltration and reverse osmosis in municipal wastewater reuse. Desalination106, $25-29$.

Johnson, W. T., Phelps, R. W. \& Beatson, P. J. 1997. Wastewater reuse using membranes. InProceedings of the World Congress on Desalination and Water Reuse, 6-9 October, Vol. II, Madrid, pp. 611-628.

Listowski, A. 1999. Recycled water system for future urban development. InProceedings of the Stormwater Industry Association 1999 Conference, April 1999 26-28, Homebush Bay, Sydney.

MHW.2007. Water Reclamation and Management Scheme. Homebush Bay, Feasibility Study, 2007. 


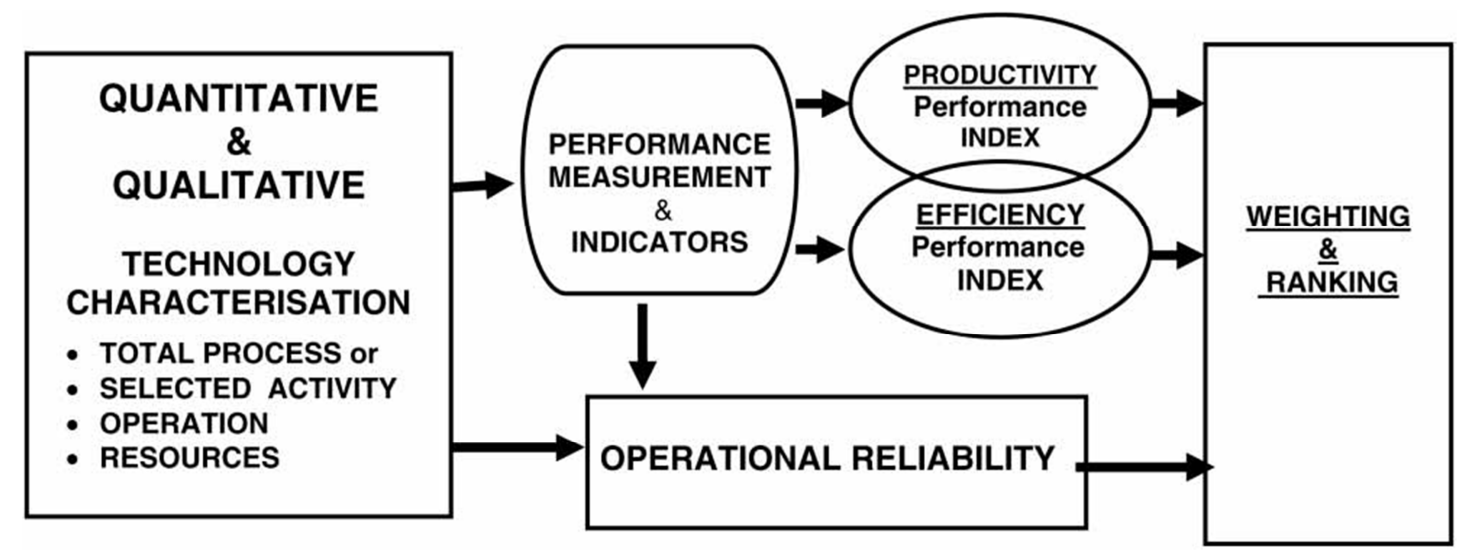

Figure 1. Technology Performance Assessment model 


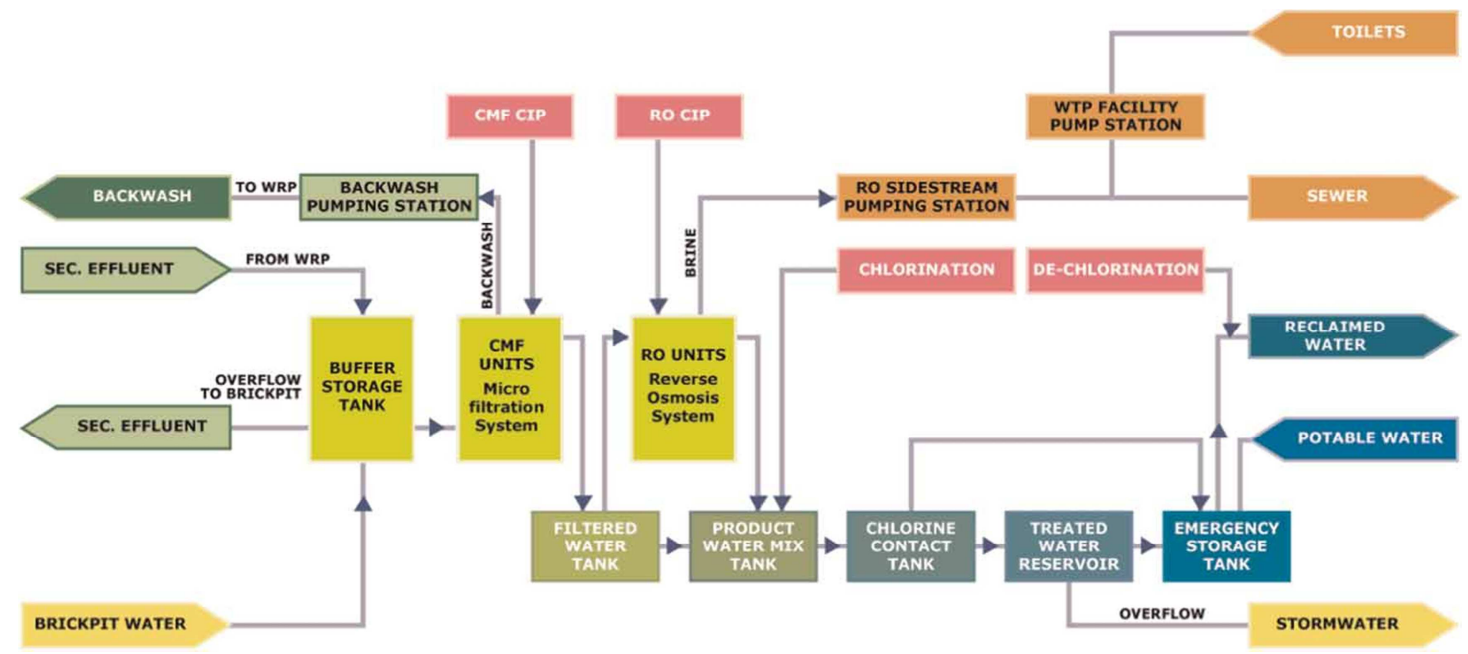

Figure 2. Water Treatment Plant (Listowski 1999) 
Table 1. Typical domestic wastewater characteristics entering WRAMS process

\begin{tabular}{|l|l|l|}
\hline Parameters & Units & Typical Value \\
\hline $\mathrm{pH}$ & - & 7.3 \\
\hline TSS & $\mathrm{mg} / \mathrm{L}$ & 139 \\
\hline TDS & $\mathrm{mg} / \mathrm{L}$ & 445 \\
\hline BOD & $\mathrm{mg} / \mathrm{L}$ & 170 \\
\hline COD & $\mathrm{mg} / \mathrm{L}$ & 363 \\
\hline Ammonia & $\mathrm{mg} / \mathrm{L}$ & 37 \\
\hline Organic $\mathrm{N}$ & $\mathrm{mg} / \mathrm{L}$ & 9 \\
\hline T. khel. $\mathrm{N}$ & $\mathrm{mg} / \mathrm{L}$ & 46 \\
\hline TN & $\mathrm{mg} / \mathrm{L}$ & 46 \\
\hline TP & $\mathrm{mg} / \mathrm{L}$ & 7.3 \\
\hline Oil \&grease & $\mathrm{mg} / \mathrm{L}$ & $<2$ \\
\hline
\end{tabular}


Table 2. Typical stormwater characteristics entering WRAMS process

\begin{tabular}{|l|l|l|}
\hline Parameters & Units & Typical Value \\
\hline $\mathrm{pH}$ & - & 8.33 \\
\hline $\mathrm{SS}$ & $\mathrm{mg} / \mathrm{L}$ & 9.55 \\
\hline TDS & $\mathrm{mg} / \mathrm{L}$ & 2000 \\
\hline FC & $\mathrm{CFU} / 100 \mathrm{~mL}$ & 300 \\
\hline TN & $\mathrm{mg} / \mathrm{L}$ & 1.82 \\
\hline TP & $\mathrm{mg} / \mathrm{L}$ & 1.41 \\
\hline Orth-phosphate & $\mathrm{mg} / \mathrm{L}$ & 1.31 \\
\hline Ammonia & $\mathrm{mg} / \mathrm{L}$ & 0.10 \\
\hline
\end{tabular}


Table 3. Recycled water and potable water quality comparison-selected parameters

\begin{tabular}{|l|l|l|l|}
\hline Parameter & Unit & Recycled water & Potable water \\
\hline E. coli & count/100 mL & $<1 / 100$ & $<1 / 100 \mathrm{~mL}$ \\
\hline FC & count/100 mL & $<1 / 100$ & $\mathrm{Na}$ \\
\hline $\mathrm{TC}$ & count/100 mL & $<1 / 100$ & $\mathrm{Na}$ \\
\hline Viruses & count/50 L & $<1$ & 0 \\
\hline Parasites & count/50 L & $<1$ & 0 \\
\hline Turbidity & $\mathrm{NTU}$ & $0.1-0.5$ & $<5$ \\
\hline $\mathrm{pH}$ & $\mathrm{Ph}$ & $6.5-8.5$ & $6.5-8.5$ \\
\hline Colour & $\mathrm{TCU}$ & 5 & $<15$ \\
\hline Aluminium & $\mathrm{mg} / \mathrm{L}$ & 0.03 & $<0.2$ \\
\hline Berylliun & $\mathrm{mg} / \mathrm{L}$ & 0.0001 & $\mathrm{Na}$ \\
\hline Cadmium & $\mathrm{mg} / \mathrm{L}$ & 0.00005 & $<0.002$ \\
\hline Calcium & $\mathrm{mg} / \mathrm{L}$ & $20-25$ & $12-14$ \\
\hline Chromium & $\mathrm{mg} / \mathrm{L}$ & 0.003 & $<0.05$ \\
\hline Copper & $\mathrm{mg} / \mathrm{L}$ & $<0.15$ & $<1$ \\
\hline Fluoride & $\mathrm{mg} / \mathrm{L}$ & $<1$ & $0.9-1.5$ \\
\hline Iron & $\mathrm{mg} / \mathrm{L}$ & 0.02 & $<0.3$ \\
\hline Lead & $\mathrm{mg} / \mathrm{L}$ & $<0.0006$ & $<0.01$ \\
\hline Magnesium & $\mathrm{mg} / \mathrm{L}$ & $2-15$ & 5.5 \\
\hline Nickel & $\mathrm{mg} / \mathrm{L}$ & $<0.02$ & $<0.02$ \\
\hline
\end{tabular}


Table 4. Water resources mass balance; average daily, monthly \& annual data

\begin{tabular}{|l|l|l|l|l|l|l|l|l|}
\hline \multicolumn{2}{|l}{ WRAMS operating parameter } & \multicolumn{2}{l}{ Daily data } \\
\hline Resource type & Unit & $1 / 10$ & $2 / 10$ & $3 / 10$ & $4 / 10$ & $5 / 10$ & Month & Year \\
\hline Sewage flow to WRP & $\mathrm{m}^{3}$ & 1765 & 1600 & 1623 & 1837 & 1794 & 52158 & 646,371 \\
\hline Sludge production & $\mathrm{m}^{3}$ & 13 & 22 & 23 & 19 & 14 & 395 & 3657 \\
\hline Effluent production & $\mathrm{m}^{3}$ & 1580 & 1630 & 1651 & 1852 & 1829 & 52525 & 653,207 \\
\hline Stormwater supply & $\mathrm{m}^{3}$ & 880 & 727 & 535 & 2461 & 2600 & 39082 & 543,533 \\
\hline Total MF feedwater & $\mathrm{m}^{3}$ & 2371 & 2255 & 2071 & 4212 & 4248 & 84705 & $1,025,562$ \\
\hline Total MF filtrate & $\mathrm{m}^{3}$ & 2121 & 1984 & 1852 & 3708 & 3509 & 72083 & 868,006 \\
\hline Total MF backwash & $\mathrm{m}^{3}$ & 537 & 335 & 271 & 621 & 832 & 13684 & 224,765 \\
\hline Total R.O. feedwater & $\mathrm{m}^{3}$ & 1515 & 1152 & 1157 & 1177 & 1491 & 33992 & 473,854 \\
\hline Total R.O. permeate & $\mathrm{m}^{3}$ & 1179 & 966 & 975 & 982 & 1246 & 25616 & 378,806 \\
\hline Total R.O. side stream & $\mathrm{m}^{3}$ & 336 & 186 & 182 & 195 & 246 & 8376 & 94,166 \\
\hline Chlorine dosing rate & $\mathrm{mg} / \mathrm{L}$ & 8 & 8 & 8 & 6 & 7 & 8 & 7 \\
\hline Potable water top-up & $\mathrm{m}^{3}$ & 999 & 999 & 992 & 999 & 1999 & 39554 & 58,426 \\
\hline Recycled water supply & $\mathrm{m}^{3}$ & 2545 & 2570 & 2727 & 4781 & 5068 & 104719 & 812,916 \\
\hline
\end{tabular}


Table 5. Quantitative indicators for microfiltration performance

\begin{tabular}{|c|c|c|c|}
\hline $\begin{array}{l}\text { Performance } \\
\text { indicator }\end{array}$ & Unit & Index target & Index value \\
\hline $\begin{array}{l}\text { MF capacity } \\
\text { (design) }\end{array}$ & $\mathrm{m}^{3} / \mathrm{d}$ & $\Sigma \mathrm{Q}_{\mathrm{MF}}=100 \%$ & 7500 \\
\hline $\begin{array}{l}\text { MF capacity } \\
\text { (average) }\end{array}$ & $\mathrm{m}^{3} / \mathrm{d}$ & $\sum \mathrm{Q}_{\mathrm{MFact}}$ & 6500 \\
\hline MF capacity ratio & $\%$ & $\sum \mathrm{Q}_{\mathrm{MFact}}=\%$ & 86,1 \\
\hline Effluent feed & $\mathrm{m}^{3} / \mathrm{d}$ & $\mathrm{Q}_{\mathrm{INF}}=$ average yield/d & 1800 \\
\hline $\begin{array}{l}\text { Stormwater feed } \\
\text { (average) }\end{array}$ & $\mathrm{m}^{3} / \mathrm{d}$ & $\mathrm{Q}_{\mathrm{ENF}}=$ average yield/d & 1500 \\
\hline $\begin{array}{l}\text { Filtrate production } \\
\text { (average) }\end{array}$ & $\mathrm{m}^{3} / \mathrm{d}$ & $\mathrm{Q}_{\mathrm{sw}}=$ average yield/d & 2380 \\
\hline $\begin{array}{l}\text { Filtrate flow rate } \\
\text { (max. rate) }\end{array}$ & $\mathrm{L} / \mathrm{s}$ & $\mathrm{Q}_{\mathrm{F}}=\mathrm{Max}$ & 25 \\
\hline $\begin{array}{l}\text { Retentate } \\
\text { production } \\
\text { (average) }\end{array}$ & $\mathrm{m}^{3} / \mathrm{d}$ & $\begin{array}{l}P_{X, V S S}=Y_{o b s}(Q) \\
\left(S_{0^{-}} S\right) 1 \mathrm{~kg} / 10^{3} \mathrm{~g}\end{array}$ & 616 \\
\hline $\begin{array}{l}\text { Electricity use by } \\
\text { membranes }\end{array}$ & $\mathrm{kWh} / \mathrm{m}^{3}$ & kWh/ MLfiltrate & 0.70 \\
\hline $\begin{array}{l}\text { Total GHG } \\
\text { emission (coef. } \\
0.92 \text { ) }\end{array}$ & $\mathrm{kgCO}_{2} / \mathrm{m}^{3}$ & $\sum \mathrm{GHG}_{\mathrm{emission}}=0$ & 0.8232 \\
\hline $\begin{array}{l}\text { Total chemicals } \\
\text { used for CIP }\end{array}$ & $\mathrm{g} / \mathrm{m}^{3}$ & $\Sigma \mathrm{M}_{\text {chem }} / \mathrm{kL}$ & 12 \\
\hline
\end{tabular}


Table 6. Qualitative characterisation of the MF performance indicators

\begin{tabular}{|l|l|l|l|}
\hline $\begin{array}{l}\text { Performance } \\
\text { indicators }\end{array}$ & Unit & $\begin{array}{l}\text { Concentration } \\
\text { feedwater }\end{array}$ & Filtrate \\
\hline BOD5 & $\mathrm{mg} / \mathrm{L}$ & 5 & 1.3 \\
\hline COD & $\mathrm{mg} / \mathrm{L}$ & 35 & 15 \\
\hline Ammonia & $\mathrm{mg} / \mathrm{L}$ & 3.8 & 0.8 \\
\hline Total nitrogen $(\mathrm{TN})$ & $\mathrm{mg} / \mathrm{L}$ & 4.1 & 3.2 \\
\hline $\begin{array}{l}\text { Total phosphorous } \\
\text { (TP) }\end{array}$ & $\mathrm{mg} / \mathrm{L}$ & 0.79 & 0.54 \\
\hline $\begin{array}{l}\text { Total suspended } \\
\text { solids (TSS) }\end{array}$ & $\mathrm{mg} / \mathrm{L}$ & $<2$ & 0 \\
\hline $\begin{array}{l}\text { Total dissolved } \\
\text { solids (TDS) }\end{array}$ & $\mathrm{mg} / \mathrm{L}$ & 660 & 600 \\
\hline pH & $\mathrm{mg} / \mathrm{L}$ & 7.7 & 7.7 \\
\hline Turbidity & NTU & 6.5 & $<1$ \\
\hline FC $(\mathrm{CFU} / 100 \mathrm{~mL})$ & No & 1700 & $<1$ \\
\hline
\end{tabular}


Table 7. Summary of microbiological virus and pathogen removal

\begin{tabular}{|l|l|l|l|}
\hline $\begin{array}{l}\text { Performance } \\
\text { parameter }\end{array}$ & Unit & $\begin{array}{l}\text { Performance } \\
\text { indicator }\end{array}$ & $\begin{array}{l}\text { Actual } \\
\text { concentration in } \\
\text { filtrate }\end{array}$ \\
\hline Cryptosporidium & Ooscysts/100L & $<2$ & 0 \\
\hline Gardia & Ooscysts/100L & $<2$ & 0 \\
\hline Hepatitis A virus & no/25L & $<2$ & Absent or 0 \\
\hline Rotavirus & no/25L & $<2$ & Absent or 0 \\
\hline Human calicvirus & no/25L & $<2$ & Absent or 0 \\
\hline Adenovirus & no/25L & $<2$ & Absent or 0 \\
\hline Reovirus & no/25L & $<2$ & Absent or 0 \\
\hline Enterovirus & no/25L & $<2$ & Absent or 0 \\
\hline
\end{tabular}


Table 8. MF microfiltration Volume Productivity Index

\begin{tabular}{|l|l|l|}
\hline Total inflow $\left(\mathrm{m}^{3} / \mathrm{d}\right)$ & Filtrate $\left(\mathrm{m}^{3} / \mathrm{d}\right)$ & Productivity index $(\mathrm{PI})$ \\
\hline 1915 & 1601 & 79.3 \\
\hline 3229 & 2738 & 81.2 \\
\hline 3205 & 2746 & 82 \\
\hline 1905 & 1681 & 76.5 \\
\hline 2235 & 1938 & 81.3 \\
\hline
\end{tabular}


Table 9. MF filtrate quality variability

\begin{tabular}{|l|l|l|l|l|l|l|}
\hline Parameter & Unit & Week 1 & Week 2 & Week 3 & Week 4 & $\begin{array}{l}\text { Geometr. } \\
\text { mean }\end{array}$ \\
\hline BOD5 & $\mathrm{mg} / \mathrm{L}$ & 1.3 & 2 & 1.5 & 1.7 & 1.60 \\
\hline COD & $\mathrm{mg} / \mathrm{L}$ & 14 & 15 & 12 & 13 & 13.45 \\
\hline TDS & $\mathrm{mg} / \mathrm{L}$ & 660 & 650 & 600 & 650 & 639.56 \\
\hline TSS & $\mathrm{mg} / \mathrm{L}$ & $<2$ & $<2$ & $<2$ & $<2$ & $<2$ \\
\hline $\begin{array}{l}\text { True } \\
\text { colour }\end{array}$ & Pt-Co & 9 & 10 & 10 & 10 & 9.74 \\
\hline pH & $\mathrm{pH}$ & 7.6 & 7.7 & 7.7 & 7.7 & 7.67 \\
\hline Turbidity & $\mathrm{NTU}$ & 2 & 2.2 & 2.2 & 2.2 & 2.15 \\
\hline $\begin{array}{l}\text { Total oil } \\
\text { \& grease }\end{array}$ & $\mathrm{mg} / \mathrm{L}$ & $<2$ & $<2$ & $<2$ & $<2$ & $<2$ \\
\hline $\begin{array}{l}\text { Ammonia } \\
\text { (as N) }\end{array}$ & $\mathrm{mg} / \mathrm{L}$ & 0.8 & 1.2 & 1.2 & 1.2 & 1.08 \\
\hline $\begin{array}{l}\text { Total } \\
\text { oxidised } \\
\text { N. }\end{array}$ & $\mathrm{mg} / \mathrm{L}$ & 0.7 & 0.84 & 0.84 & 0.84 & 0.80 \\
\hline $\begin{array}{l}\text { Total kjel. } \\
\text { Nitr. }\end{array}$ & $\mathrm{mg} / \mathrm{L}$ & 2.3 & 2.4 & 2.4 & 2.4 & 2.37 \\
\hline $\begin{array}{l}\text { Total } \\
\text { nitrogen }\end{array}$ & $\mathrm{mg} / \mathrm{L}$ & 2.8 & 3.2 & 3.2 & 3.2 & 3.09 \\
\hline $\begin{array}{l}\text { Total } \\
\text { phosp. }(\mathrm{as} \\
\text { P) }\end{array}$ & $\mathrm{mg} / \mathrm{L}$ & 0.45 & 0.54 & 0.54 & 0.54 & 0.52 \\
\hline
\end{tabular}


Table 10. MF reliability Index

\begin{tabular}{|l|l|l|l|l|}
\hline $\begin{array}{l}\text { Treatment } \\
\text { process } \\
\text { element }\end{array}$ & $\begin{array}{l}\text { Total time } \\
\text { available }(\mathrm{h})\end{array}$ & $\begin{array}{l}\text { Time between } \\
\text { failures TBF } \\
(\mathrm{h} / \text { year })\end{array}$ & $\begin{array}{l}\text { Downtime } \\
\text { TOR }(\mathrm{h} / \mathrm{yaer})\end{array}$ & $\begin{array}{l}\text { Reliability } \\
\text { index }-\mathrm{R}_{\mathrm{OPS}} \\
(\%)\end{array}$ \\
\hline Microfiltration & 8760 & 8642 & 18 & 99.77 \\
\hline
\end{tabular}


Table 11. Microfiltration efficiency analysis based on water recovery rate

\begin{tabular}{|l|l|l|l|l|l|l|}
\hline $\begin{array}{l}\text { Feed } \\
(\mathrm{kL} / \mathrm{d})\end{array}$ & $\begin{array}{l}\text { Filtrate } \\
\left(\mathrm{m}^{3} / \mathrm{d}\right)\end{array}$ & $\begin{array}{l}\text { Backwash } \\
\left(\mathrm{m}^{3} \mathrm{~L}\right)\end{array}$ & $\begin{array}{l}\text { Time } \\
(\mathrm{h} / \mathrm{d})\end{array}$ & $\begin{array}{l}\text { Non-productive } \\
\text { time }(\mathrm{h} / \mathrm{d})\end{array}$ & $\begin{array}{l}\text { MF } \\
\text { backwash } \\
(\mathrm{no} / \mathrm{d})\end{array}$ & $\begin{array}{l}\text { MF } \\
\text { recovery } \\
\text { efficiency } \\
\text { rate }(\%)\end{array}$ \\
\hline 3090.9 & 2779.3 & 426.7 & 22.3 & 1.7 & 51 & 89.92 \\
\hline
\end{tabular}


Table 12. Microfiltration efficiency-pollutants removal

\begin{tabular}{|l|l|l|}
\hline Parameter & Unit & $\begin{array}{l}\text { MF Removal Efficiency } \\
\text { Index (CMF) }\end{array}$ \\
\hline Biological oxygen demand & $\mathrm{mg} / \mathrm{L}$ & 74 \\
\hline Chemical oxygen demand & $\mathrm{mg} / \mathrm{L}$ & 60 \\
\hline Total dissolved solids & $\mathrm{mg} / \mathrm{L}$ & 2 \\
\hline Suspended solids & $\mathrm{mg} / \mathrm{L}$ & 87 \\
\hline True colour & $\mathrm{Pt}-\mathrm{Co}$ & 67 \\
\hline pH & $\mathrm{pH}$ & 1 \\
\hline Turbidity & $\mathrm{NTU}$ & 69 \\
\hline Total oil and grease & $\mathrm{mg} / \mathrm{L}$ & 75 \\
\hline Ammonia (as N) & $\mathrm{mg} / \mathrm{L} \mathrm{N}$ & 58 \\
\hline Total oxidised nitrogen & $\mathrm{mg} / \mathrm{L} \mathrm{N}$ & 36 \\
\hline Total kjel. Nitrogen $(\mathrm{calc})$ & $\mathrm{mg} / \mathrm{L} \mathrm{N}$ & 23 \\
\hline Total nitrogen & $\mathrm{mg} / \mathrm{L} \mathrm{N}$ & 32 \\
\hline Total phosp $($ as $\mathrm{P})$ & $\mathrm{mg} / \mathrm{L} \mathrm{P}$ & 33 \\
\hline
\end{tabular}


Table 13. MF microfiltration energy and chemicals use

\begin{tabular}{|l|l|l|l|}
\hline Parameter & Value & $\begin{array}{l}\text { Total energy use } \\
(\mathrm{kWh})\end{array}$ & $\begin{array}{l}\text { Energy use rate } \\
\mathrm{kWh} / \mathrm{m}^{3}\end{array}$ \\
\hline $\begin{array}{l}\text { Filtrate production } \\
(\mathrm{kL} / \mathrm{d})\end{array}$ & 1927.6 & 15.91 & 0.83 \\
\hline $\begin{array}{l}\text { Reject production } \\
(\mathrm{kL} / \mathrm{d})\end{array}$ & 3.78 & 0.10 & 0.026 \\
\hline $\begin{array}{l}\text { CIP operation } \\
(\text { no/month })\end{array}$ & 2 & 0.36 & - \\
\hline $\begin{array}{l}\text { Chemicals for CIP } \\
(\mathrm{L} / \mathrm{yr})\end{array}$ & 2000 & - & - \\
\hline $\begin{array}{l}\text { Chemicals } \\
(\text { Ant.Scalant })\end{array}$ & 300 & - & - \\
\hline (L/yr) $)$ & 2000 & - & - \\
\hline $\begin{array}{l}\text { Chemicals } \\
\text { (biocide) }(\mathrm{L} / \mathrm{yr}))\end{array}$ & & & \\
\hline
\end{tabular}

